\title{
Аналіз організації керування обладнанням для забезпечення транспортування зернової продукції на елеваторах
}

\author{
В.А. Мардзявко \\ Харківський національний технічний університет сільського господарства \\ імені Петра Василенка (м. Харків, Україна) \\ email: vitalijmardzavko@gmail.com
}

\begin{abstract}
У статті представлено аналіз методів які забезпечують організацію і керування технологічним процесом транспортування зернової продукції на елеваторі для визначення можливостей подальшої автоматизації. Актуальність даної теми обґрунтовується виходячи з неповної продуктивності технологічного процесу транспортування на елеваторах, через те, що автоматизована система керування елеватора реалізує автоматизовані задачі за допомогою стандартних методів транспортування, а саме за транспортно-технологічними маршрутами. Організація і функціональна структура, як підприємств, так і автоматизованої системи, залишається без змін, тому і якість керування істотно не змінюється. Хоча дані методи і мають перевагу над іншими, проте вони не в повну міру забезпечують енергозбереження під час технологічних процесів транспортування, умов, які б відповідали забезпеченню якості зернової продукції, зменшення втрат зерна під час транспортування та високої продуктивності підприємства. Однак завданням автоматизованого виробництва $є$ забезпечення умов для підвищення якості технологічного процесу, тому виникає актуальне питання розробки нових або удосконалення існуючих заходів і створення нових продуктивних систем на їх основі. Тому виходячи з даної проблеми, був виконаний аналіз основних системи керування обладнанням на елеваторах, та визначений найбільш ефективний метод формування маршруту транспортування зернової продукції. Також виявлені недоліки та основні напрямки подальшого удосконалення даного методу. Увагу акцентовано на важливості правильного та оптимального прокладання маршруту, завдяки чому визначено критерії які не враховувалися в традиційних методах забезпечення технологічного процесу транспортування.
\end{abstract}

Ключові слова: елеватор, побудова маршруту, автоматизована система, ручне керування, дистанційне керування, система SCADA, критерії оптимізації.

Вступ. Одним з головних елементів в раціоні харчування людини, корму для тварин та сировини для багатьох галузей промисловості, є зернові продукти. На сьогоднішній день надійним місцем зберігання та транспортування зерна $€$ зернові елеватори, в яких також можна поліпшити якість зерна [1].

Основні споруди елеватора - робоча вежа, силосний корпус, приймальні та відпускні пристрої. У робочій вежі розміщені: норії, ваги, зерноочисні машини, самопливне і аспираційне обладнання, привідні й натяжні станції транспортерів елеватора [2]. Тому в залежності від об'ємів зернової продукції та обладнання, яке буде застосовуватися для його переробки і транспортування, постає питання раціональної та правильної організації керування обладнанням на елеваторах.

Керування технологічним процесом на елеваторах необхідно здійснювати шляхом розробки та постійного удосконалення технологічних ліній, які б забезпечували ефективне виконання всіх необхідних операцій за допомогою наявного обладнання, способів механізації та автоматизації з найменшими витратами праці і матеріалів.
Технологічна схема переміщення зерна по елеватору підпадає частим змінам, так як майже кожна операція з зерном потребує налаштування маршруту його переміщення, тобто організації руху зерна територією елеватора в необхідному напрямку за допомогою строго визначених, попередньо зазначених механізмів.

При розробці системи керування елеватора висуваються задачі дотримання умов, які б забезпечували зберігання, вимог якості продукції при одночасному транспортуванні зерна за декількома маршрутами.

Для виконання вимог якості, система керування повинна забезпечити:

- запобігання можливості змішування зерна, що одночасно рухається різними маршрутами;

- послідовне увімкнення в роботу обладнання яке зазначене на маршруті від кінця до початку i його вимкнення в зворотному порядку;

- надійну роботу всього обладнання маршруту транспортування і наявність швидкого інформування при виникненні несправності.

Від правильного налаштування маршрутів переміщення продукції залежить повне вико- 
ристання потужності елеватора: зменшення простою машин, краще використання і завантаження норій та потужності електродвигунів, що значно впливає на витрати електроенергії і добову продуктивність елеватора.

Таким чином, постає питання у правильному виборі і налаштуванні маршруту переміщення продукції на елеваторі для покращення його показників.
Мета статті. Аналіз методів організації і керування технологічним процесом транспортування зернової продукції на елеваторі для визначення подальших можливостей його оптимізації.

Викладення основного матеріалу. Залежно від виду і досконалості обладнання керування елеваторами влаштовують за різними схемами: ручне керування, дистанційне керування, автоматизоване керування.

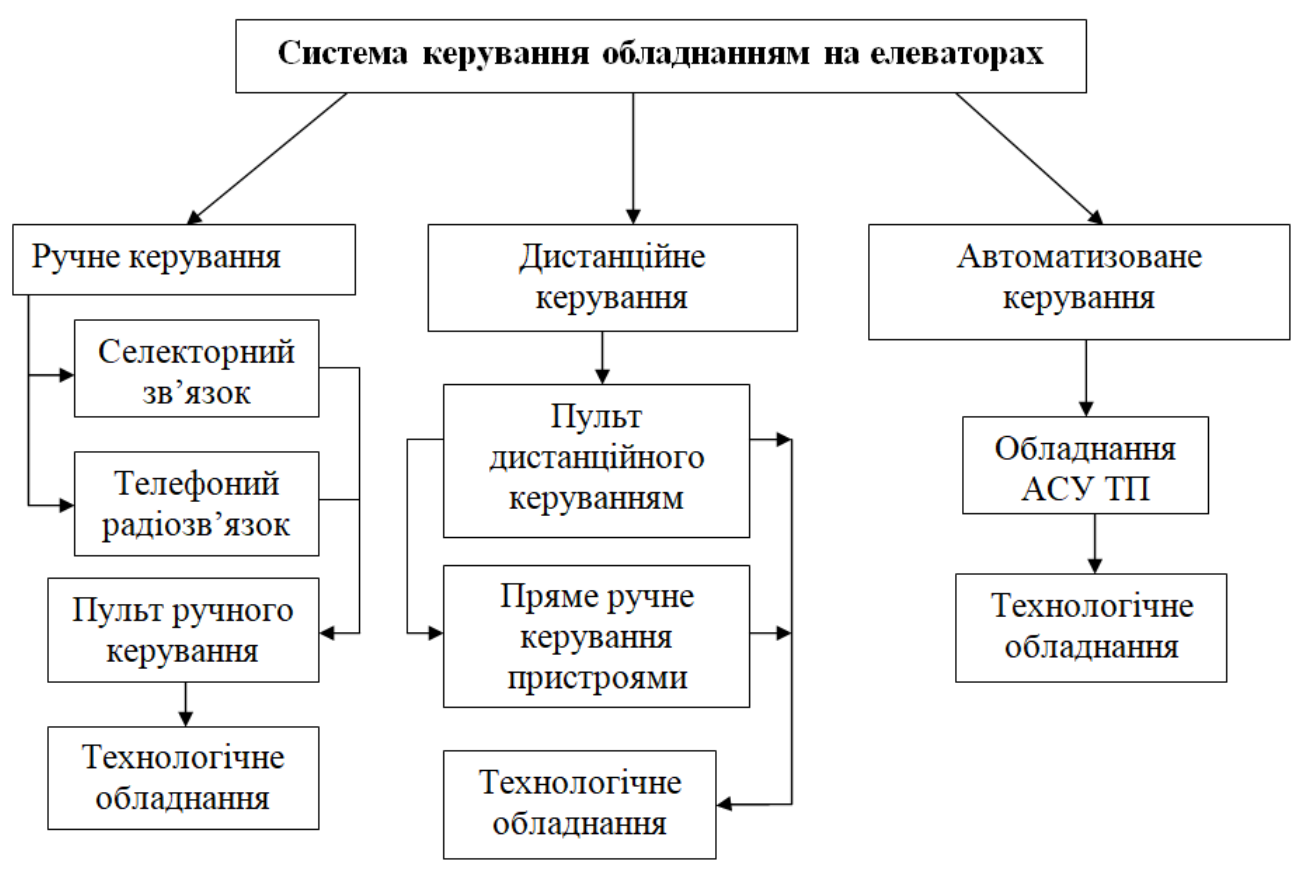

Рис. 1. Схема забезпечення керування обладнанням на елеваторах

На схемі (рис.1) зазначені основні способи забезпечення технологічного процесу транспортування зерна, що відображає покрокове налаштування і керування маршрутом.

Найпершим і найпримітивнішим методом $€$ ручне керування, яке характеризується великими витратами ручної праці для забезпечення процесу транспортування зерна як з боку диспетчера, так і з боку працівників, які безпосередньо знаходяться біля обладнання. В даному способі за розпорядженням диспетчера робочі елеватора виконують операції зі встановлення в задане положення розподільних пристроїв, виконуючи пряме керування обладнанням. Диспетчер особисто обирає та прокладає маршрут транспортування зерна. Для зв'язку з робочими місцями і видачі команд, залежно від розмірів елеватора та обсягу його операцій, використовують: селекторний чи радіозв'язок. Вони відрізняються лише якістю і рівнем мобільності зворотного зв'язку між оператором і працівником. Оцінку правильності завантаження обладнання оператор виконує за допомогою вимірювальних приладів, які знімають показники сили струму, що надходить до електродви- гуна. За показниками ватметра або амперметра, оператор оцінює навантаження обладнання, а отже, може надати вказівку працівникам елеватора про зміну висипу зерна, якщо остання не відповідає прийнятій нормі [4].

Дивлячись на структурну схему даного методу, можна зробити висновок, що ця система керування недосконала. Вона вимагає багато часу на налаштування маршруту, що значно впливає на ефективність роботи елеватора,а також не забезпечує диспетчера надійною інформацією про правильність виконання його розпоряджень, ступеня заповнення та завантаження устаткування. Відомості про несправності будь-якої машини, що входить в маршрут, диспетчер отримує з запізненням, що може привести до засипання норії [3]. Крім того великі витрати ручної праці на забеспечення процесу керування обладнанням позитивно не впливає на здійснення технологічного процесу елеватора. Присутність робітників на всіх поверхах елеватора при важких умовах роботи, особливо в зимовий період, не дає можливості поліпшити якість виконання роботи. 
Наступна - схема дистанційного керування. В даному випадку вибір і регулювання маршруту транспортування зерна також виконується оператором. Але в порівнянні з попередньою схемою керування, з'являється можливість дистанційно керувати всіма операціями з регулювання висипу зерна, але деякі вузли схеми залишаються децентралізованими (очищення, сушіння та деякі інші) [4].

Наявність часткового дистанційного керування вже свідчить про більшу надійність та досконалість системи, порівняно з попередньою. Більш ефективне виконання всіх необхідних операцій отримується за допомогою електроприводу для кожного виконавчого механізму, що дозволяє вмикати в роботу лише ті електродвигуни, які необхідні для налаштування певного маршруту,дозволяючи підвищити продуктивність та економію електроенергії. Дана можливість отримується за рахунок електричних пристроїв, які включають в себе різні датчики, реле, магнітні пускачі. Так, пуск і зупинка електродвигунів приводів транспортного, технологічного та аспіраційного обладнання здійснюється пультовим керуванням. Разом з тим отримується можливість виконання блокування необхідних двигунів, що забезпечує задану послідовність запуску і зупинки машин. Керування технологічною лінією даним методом також передбачає дистанційний контроль ступеня завантаження норій за допомогою амперметра, включеного в мережу електропостачання електродвигуна. У норій (для захисту їх від завалів) встановлюють засувки 3 виконавчим механізмом, які закриваються в разі надходження сигналів про заповнення бункера. Заповнення бункерів контролюють встановленими в них датчиками рівня зерна [3].

Зазначена схема керування в порівнянні з попередньою $€$ більш безпечною та продуктивнішою, що значно відображується на якості забезпечення технологічного процесу елеватора. Схема керування обладнанням, що має у своїй конструкції незалежні електроприводи, отримала можливість перебудови маршруту під зміну вимог технологічного процесу підприємства. Однак в даному типі керування присутнє обладнання яке все ж пристосоване тільки до ручного керування, що значно ускладнює процес переробки структурної схеми транспортування, до такого обладнання відносять візки надсилосних транспортерів, розподільні пристрої та засувки. В даному обладнанні дистанційне керування не забезпечує високого ступеня захисту струмопровідних частин механізмів, що у свою чергу призводить до підвищення небезпеки обслуговуючого персоналу і неможливості оптимізації процесу керування [8]. Також до недоліків даної системи керування можна віднести потребу у великій кількості працівників і механізмів, що призводить до збільшення витрат на переробку продукції. Зазначена система керування хоч і $€$ менш трудомісткою та продуктивнішою, але вона не забезпечує в достатній мірі умов, які б відповідали вимогам поліпшення якості продукції.

Подальший розвиток обладнання привів до появи нових систем керування виробництвом, 3 керуючими засобами, що ґрунтуються на застосуванні електронних обчислювальних машин,програмованих логічних контролерів, програмного забезпечення і т.д. [8].

При автоматизованому керуванні елеватором керування технологічними процесами максимально полегшується та покращується. Можна автоматизовано керувати всім обладнанням, яке забезпечує маршрут переміщення зерна, отримувати сигнали про роботу обладнання, про положення розподільних пристроїв, про рівень заповнення силосів, про ступінь завантаження норій. Система передбачає автоматичне блокування елементів технологічної лінії, що забезпечує можливість послідовного регулювання маршруту і пуску обладнання та виключає змішування різних партій зерна [3].

Для забезпечення вирішення завдання автоматизації елеватора, використовується наступна структурна схема системи керування (рис.2):

Все обладнання системи автоматизації елеватора будується за блочно-модульним принципом. Модульно-блочний принцип побудови дозволяє легко модернізувати систему і, в міру необхідності, додавати в неї нові елементи, поступово охоплюючи додаткові ділянки виробництва.

Із структурної схеми (рис.2) видно основні блоки системи керування: щит керування, щит 3 програмованим логічним контролером, робоче місце оператора на основі SCADA-системи. Такий розподіл ролей між елементами системи автоматизації підвищує продуктивність і надійність системи в порівнянні з класичними рішеннями керування елеваторами [6].

В силовому щиті (щит керування) (рис.2) зосереджена пускорегулююча апаратура, датчики струму і модулі контролера, так звані пристрої віддаленого збору та керування. Він відповідає за подачу електроенергії на електродвигуни устаткування, захист обладнання від перевантажень і коротких замикань; електричні схемні блокування; приймання вхідних сигналів від датчиків; забезпечення можливості місцевого керування обладнанням.

Щит з програмованим логічним контролером (ПЛК) (рис.2) забезпечує керування обладнанням силового щита за допомогою цифрового інтерфейсу. Він відіграє одну з основних ролей для забезпечення автоматизації в елеваторній системі, так як на нього покладена основна частина алгоритмів керування і захисту обладнання. 


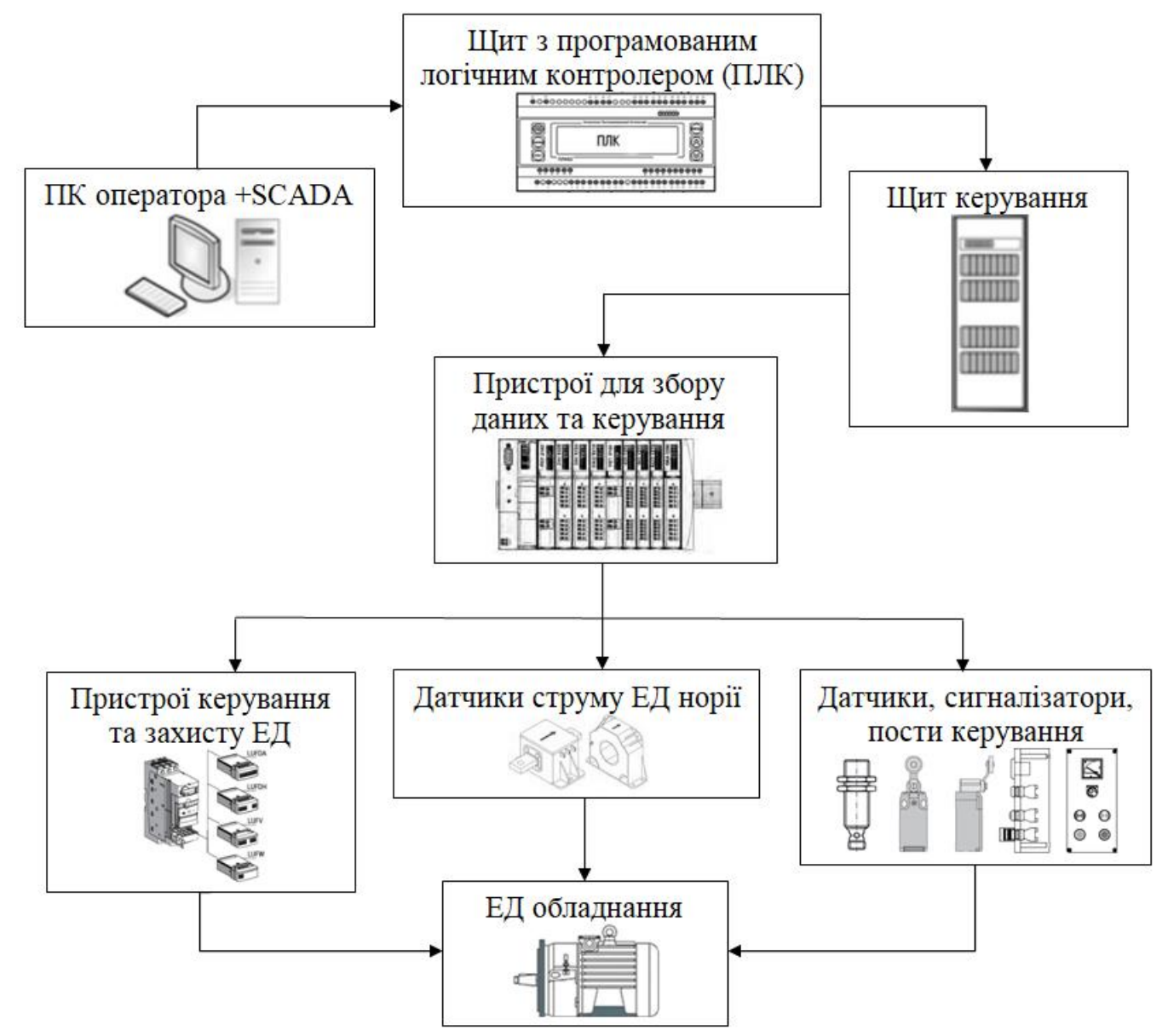

Рис.2 Структурна схема системи автоматизованого керуваннятехнологічним процесом на елеваторі

Наступним блоком з якого подаються команди є диспетчерська оператора (рис.2), основною складовою якого є система SCADA. Даний елемент системи забезпечує надання інформації оператору про роботу попередніх блоків і можливість дистанційного керування обладнання. При цьому на SCADA-систему покладений найбільш складний елемент контролю, а саме автоматизація прокладки маршруту транспортування зерна. Для того, щоб система проклала маршрут, необхідно виконати програмування кожного керуючого пристрою обладнання (норій, транспортерів, клапанів, засувок і силосів).

Завдяки цьому, у порівнянні 3 попередніми способами керування елеваторами, витрати ручної праці зменшуються до мінімуму та полегшується робота оператора. Оператору необхідно натиснути кнопку "Побудова маршруту" на комп'ютері, після чого йому необхідно буде обрати початкову і кінцеву точку транспортування. В результаті керуючий контролер починає аналіз можливості прокладання даного маршруту. Якщо така можливість $€$, то на операторському дисплеї висвітиться кнопка "Підготувати маршрут". Далі виконавчі та регулюючі елементи обладнання приймуть положення відповідно до прокладеного маршруту і стане активна кнопка "Запустити маршрут". При натисканні на неї керуюча програма почне послідовний запуск обладнання відповідно до заданого маршруту [7]. Загальний алгоритм прокладання маршруту представлений на рисунку 3.

Розглядаючи даний спосіб керування обладнанням, видно що він найкраще підходить для забезпечення якісного керування технологічним процесом на елеваторі. Впровадження даної системи зменшить ймовірність виникнення аварійного простою обладнання за рахунок відстеження його роботи, тобто швидкого інформування оператора про перебіг процесу транспортування. А наявність системи яка допомагає автоматично прокладати маршрут, забезпечує повну завантаженість та підвищує мобільність підприємства. Завдяки цьому на елеваторах можна одночасно працювати з 6-7 маршрутами, можна приймати 2 культури, 2 відвантажувати та 2 транспортувати на сушку.

Внаслідок раціонального використання обладнання підвищується продуктивність та зменшуються енерговитрати на транспортній лінії. 


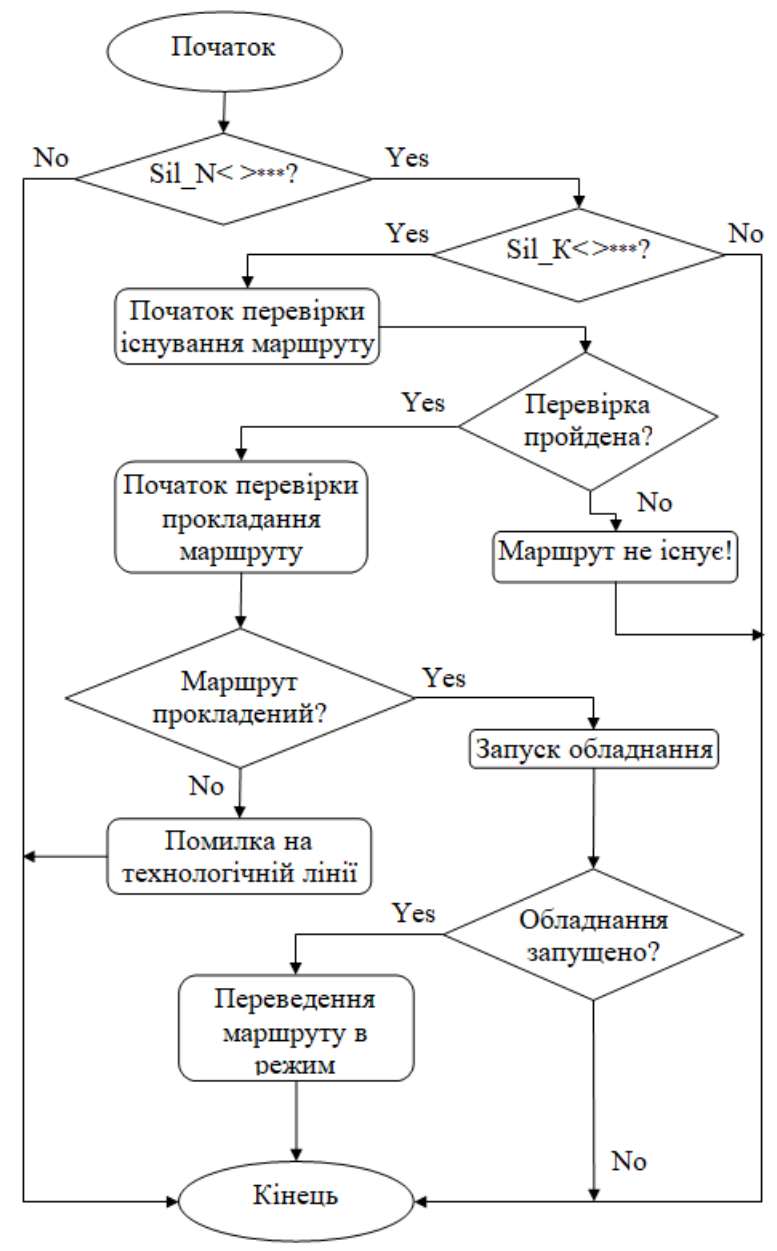

Рис. 3 Алгоритм автоматичного прокладання маршруту транспортування зерна

При порівнянні автоматизованої системи із застарілими способами керування, показники енерговитрат процесу обробки на одну тонну зерна зменшуються до 30\%, а можливість швидкого процесу прокладання маршруту транспортування збільшує швидкість завантаження засобів транспортування зернової продукції [10]. Можливість швидко вантажити маршрути - це ще не остання перевага автоматизованого зерносховища. Основною являється здатність підприємства вирівнювати та коригувати якість зерна на експорт та генерація додаткового прибутку за рахунок складання необхідного технічного завдання і внесення змін в керуючу програму формування маршрутів переміщення зерна. Однак наявність такої складної та багатокомпонентної системи має і недолік - це вартість даної системи, яка обмежує застосування системи автоматизації на елеваторах малих потужностей і об'ємів. 3 цього фракту також випливає складність обслуговування автоматизованого комплексу. Для цього може знадобитися спеціаліст з електроніки або комп'ютерних технологій, щоб допо- могти в обслуговуванні та оновити технічне та програмне забезпечення, які необхідні для інтенсивного використання автоматизованої системи керування. Або, як альтернатива, провести відповідні заходи для забезпечення власних працівників відповідними знаннями в обслуговувані комплексу, що в першому так і у другому випадку призведе до додаткових витрат. Однак у порівнянні з витратами на забезпечення технологічного процесу попередніх систем керування, зазначені витрати все ж будуть раціональними. Наступний недолік пов'язаний 3 тим, що внаслідок недостатнього досвіду використання SCADA - систем в галузі, що розглядається, їх можливості не в повній мірі використовуються. Наявність комп'ютера в системі дозволяє розвинути програмне забезпечення, реалізувавши елементи штучного інтелекту при прокладанні маршрутів транспортування продукції. Наразі оператору пропонується маршрут тільки з обмеженого списку штатних маршрутів, або можливість включати чи змінювати маршрут вручну, що, виходячи 3 наявності людського фрактора, може призвести до виникнення помилок. Тому, на даному етапі автоматизації технологічного процесу на елеваторах, система SCADA, практично не реалізує завдання автоматичного прокладання маршруту транспортування зерна. 3 чого виникає задача подальшого розвитку функціональних можливостей даних систем, а саме можливість прокладання оптимального маршруту в поточний момент часу з урахуванням факторів які можуть вплинути на характеристику маршруту. Оптимізація прокладеного маршруту може відбуватися за кількома критеріями: кількість обладнання, в залежності від координат точок А (початку) і В (кінця) маршруту; споживання електроенергії; швидкість транспортування, якість продукції.

Висновок. Проаналізувавши методи та системи керування технологічними процесами транспортування зерна на елеваторі, можна відмітити, що вони зазнали значних змін, завдяки прогресу у комп'ютерних технологіях та засобах автоматизації виробництв. Основними та спільними недоліками застарілих систем керування, було: низька продуктивність підприємства; неможливість точного інформування і відстежування стану протікання технологічного процесу; неможливість забезпечення якісного захисту та цілісності прокладеного маршруту, а впровадження автоматизованої системи забезпечує усунення всіх перерахованих недоліків. Взаємодія оператора та автоматизованої системи на даний час дозволяє зробити робоче середовище безпечнішим та ефективнішим, але не стовідсотково. 3 вище зазначеного аналізу можна стверджувати, що існуючі система SCADA не в повній 
мірі виконує функцію автоматизації прокладання маршруту. Існуючі алгоритми побудовані так, що обирається перший вільний наявний маршрут із заздалегідь запрограмованих. Маршрути програмуються без урахування критеріїв оптимальності (мінімум енерговитрат і ефективності транспортування продукції), які б підвищили продуктивність технологічного процесу. Внаслідок чого система керування не дозволяє виконувати технологічні операції по оптимізації маршруту, а саме можливості обходу обладнання яке вийшло з ладу, шляхом створення альтернативного чи прокладання коротшого і раціональнішого маршруту. В якості умов побудови оптимального маршруту може служити критерії сумарного часу транспортування, довжина маршруту, енергоощадність, якість зерна. Тому наразі проблема удосконалення алгоритмів керування в напрямку оптимізації технологічних процесів елеватора за багатьма критеріями є актуальною.

\section{Література:}

1. Бурков А. И. Зерноочистительные машины. Конструкция, исследование, расчет и испытание / А. И. Бурков, Н. П. Сычугов. - Киров: НИИСХ Северо-Востока, 2001. - 261 с.

2. Элеваторы, склады, зерносушилки: навчальний посібник / К.В. Винокуров, С.Н. Никоноров. - Саратов: Саратовский государственный технический университет, 2008. - 88 с.

3. Управление работой оборудования на элеваторе. Зерновые Культуры и Элеваторы: вебсайт. URL: http://grainelevators.ru/prostoe_upravlenie.php (дата звернення: 25.11.2020).

4. Воронцов О.С. Элеваторы, склады и зерноперерабатывающие предприятия / О.С. Воронцов. - Москва: Техническая и экономическая литература по вопросам хлебопродуктов, 2000. - 270 с.

5. Володин В.В. Разработка АСУ ТП элеватора / В.В. Володин. // ИСУП. - 2005. - №3. - С. 8-12.

6. Структура АСУ ТП элеваторов и зернохранилищ. Автоматизация технолоических процессов НЕПТУН - ЭЛЕКТРО: веб-сайт. URL: http://www.elevatorasu.com/ asu_tp/structure.php (дата звернення: 02.12.2020).

7. Решение задач автоматизации элеваторного комплекса / В.С. Кудряшов, М.В. Алексеев, А.В. Иванов, К.И. Сурин. // Вестник ВГУИТ. 2018. - №1. - С. 117 - 123.

8. Бисвас К. Автоматизированная система управления распределительными кругами элеватора № 1 ЗАО Єфес Казань / К. Бисвас, В.Ю. Корнилов. // Проблемы энергетики. - 2015. - №1. - С. 123-132.

9. Чубук Л. П. Інвестування у зерносховища: порівняння та вибір альтернативних варіантів / Л.П. Чубук. // Глобальні та національні проблеми економіки. - 2015. - №8. - С. 677-682.

10. Старый или новый элеватор: где найдешь, где потеряешь? Elevatorist.com.: вебсайт. URL: https://elevatorist.com/spetsproekt/105staryiy-ili-novyiy-elevator-gde-naydesh-gde-poteryaesh. (дата звернення: 01.12.2020).

\section{References:}

1. Burkov A.I. and Sychugov N.P. (2001) Zernoochistitel'nye mashiny. Konstrukcija, issledovanie, raschet $i$ ispytanie. Kirov: NIISH Severo-Vostoka. 261 p.

2. Vinokurov K. V. and Nikonorov S. N. (2008) Jelevatory, sklady, zernosushilki: navchalnyi posibnyk. Saratov: Saratovskij gosudarstvennyj tehnicheskij universitet. $88 \mathrm{p}$.

3. Upravlenie rabotoj oborudovanija na jelevatore. Zernovye Kul'tury $i$ Jelevatory. Available at: http://grainelevators.ru/prostoe_upravlenie.php (Accessed: 25 November 2020).

4. Voroncov O. S. (2000) Jelevatory, sklady $i$ zernopererabatyvajushhie predprijatija. Moskva: Tehnicheskaja i jekonomicheskaja literatura po voprosam hleboproduktov. $270 \mathrm{p}$.

5. Volodin V. V. (2005) 'Razrabotka ASU TP jelevatora', ISUP, (3), pp. 8-12.

6. Struktura ASU TP jelevatorov $i$ zernohranilishh. Avtomatizacija tehnoloicheskih processov NEPTUN - JeLEKTRO. Available at: http://www.elevatorasu.com/ asu_tp/structure.php (Accessed: 02 December 2020).

7. Kudrjashov V.S., Alekseev M.V., Ivanov A.V. and Surin K. I. (2018) 'Reshenie zadach avtomatizacii jelevatornogo kompleksa', Vestnik VGUIT, (1), pp. 117-123.

8. Bisvas K. and Kornilov V. Ju. (2015) 'Avtomatizirovannaja sistema upravlenija raspredelitel'nymi krugami jelevatora № 1 ZAO Efes Kazan', Problemy jenergetiki, (1), pp. 123-132.

9. Chubuk L. P. (2015) 'Investuvannja u zernoshovishha: porivnjannja ta vibir al'ternativnih variantiv', Global'ni ta nacional'ni problemi ekonomiki, (8), pp. 677-682.

10. Staryj ili novyj jelevator: gde najdesh', gde poterjaesh'?. Elevatorist.com. Available at: https://elevatorist.com/spetsproekt/105-staryiy-ili-novyiy-elevator-gde-naydesh-gde-poteryaesh (Accessed: 01 December 2020).

\section{Аннотация}

\section{Анализ организации управления оборудованием для обеспечения транспортировки зерновой продукции на элеваторах}

\section{В.А. Мардзявко}

В статье представлен анализ методов обеспечивающих организацию и управление технологическим процессом транспортировки зерновой продукции на элеваторе для определения возможностей дальнейшей автоматизации. Актуальность данной темы обосновывается исходя из неполной произ- 
водительности технологического процесса транспортировки на элеваторах, потому, что автоматизированная система управления элеватора реализует автоматизированные задачи с помощью стандартных методов транспортировки, а именно за транспортно - технологическими маршрутами. Организация и функциональная структура, как предприятий, так и автоматизированной системы, остается без изменений, так и качество управления существенно не меняется. Хотя данные методы и имеют преимущество перед другими, однако они не в полную меру обеспечивают условий энергосбережения при технологических процессах транспортировки, условий, соответствующих обеспечению качества зерновой продукции, уменьшение потерь зерна при транспортировке и высокой производительности предприятия. Также известно, что задачей автоматизированного производства является обеспечение условий для повышения качества технологического процесса, поэтому возникает актуальный вопрос разработки новых или усовершенствование существующих мер и создание новых производительных систем на их основе. Поэтому исходя из данной проблемы, был выполнен анализ основных системы управления оборудованием на элеваторах, и определенный наиболее эффективный метод формирования маршрута транспортировки зерновой продукции. Также выявлены недостатки и основные направления дальнейшего совершенствования данного метода. Внимание акцентировано на важности правильного и оптимального прокладки маршрута, благодаря чему определены критерии которые не учитывались в традиционных методах обеспечения технологического процесса транспортировки.

Ключевые слова: элеватор, построение марирута, автоматизированная система, ручное управление, дистанционное управление, система SCADA, критерии оптимизации.

\section{Abstract \\ Analysis of the equipment management organization to ensure the transportation of grain products on elevators}

\section{V.A. Mardziavko}

The article presents an analysis of methods that provide the organization and management of the technological process of transportation of grain products in the elevator to determine the possibilities of further automation. The relevance of this topic is justified on the basis of incomplete productivity of the technological process of transportation in elevators, due to the fact that the automated control system of the elevator implements automated tasks using standard methods of transportation, namely transport and technological routes. The organization and functional structure of both enterprises and the automated system remain unchanged, so the quality of management does not change significantly. Although these methods have an advantage over others, they do not fully ensure energy savings during transportation processes, conditions that would meet the quality of grain products, reduce grain losses during transportation and high productivity of the enterprise. However, the task of automated production is to provide conditions for improving the quality of the technological process, so there is an urgent issue of developing new or improving existing measures and creating new productive systems based on them. Therefore, based on this problem, the analysis of the main control system of equipment on elevators was performed, and the most effective method of forming the route of grain transportation was determined. The shortcomings and main directions of further improvement of this method are also revealed. Attention is focused on the importance of correct and optimal routing, which identifies criteria that were not taken into account in traditional methods of ensuring the technological process of transportation.

Keywords: elevator, route construction, automated system, manual control, remote control, SCADA system, optimization criteria.

\section{Бібліографічне посилання/ Bibliography citation: Harvard}

Mardziavko, V. A. (2020) 'Analysis of the equipment management organization to ensure the transportation of grain products on elevators', Engineering of nature management, (4(18), pp. 35 - 41.

Подано до редакції / Received: 12.10.2020

ISSN 2311-1828

http://enm.khntusg.com.ua
Інженерія природокористування, 2020, №4(18), с. 35 - 41

Engineering of nature management, 2020, \#4(18), p. 35 - 41 